DOI: $10.17516 / 1997-1370-0818$

УДК 378.046 .4

\title{
Efficiency of the Professional Development of a Teacher in the System of Further Training: Analysis of Educational Teachers' Needs
}

\author{
Svetlana O. Petrova* \\ North-Eastern Federal University named after M. K. Ammosov \\ Yakutsk, Russian Federation
}

Received 07.04.2021, received in revised form 04.06.2021, accepted 10.08.2021

\begin{abstract}
The purpose of the study is to determine the optimal type of training in the course of teachers' professional development and to identify the expected results of this process. A questionnaire survey of secondary school teachers from 3 cities and 25 districts of the Republic of Sakha was conducted. Based on the obtained results and conclusions, the recommendation is made to develop courses with an analytical structure, focused on the organization of advisory support throughout the course, solving cases in the school context, review of strategies suitable for handling the actual learning task. Moreover, this structure is suitable for both online and offline learning courses. Also, a separate course on the development of professional ethics of a teacher in distance and offline learning formats is required. This can be seen as an urgent task of the modern teacher's activity, which leads to the success of the implementation of state policy in the educational field.
\end{abstract}

Keywords: skills development, advanced training courses, continuous professional development of the teacher, professional standard for teachers.

Research area: pedagogy.

Citation: Petrova, S. O. (2021). Efficiency of the professional development of a teacher in the system of further training: analysis of educational teachers' needs. J. Sib. Fed. Univ. Humanit. soc. sci., 14(9), 1277-1285. DOI: $10.17516 / 1997-1370-0818$

(C) Siberian Federal University. All rights reserved

* Corresponding author E-mail address: petrovasvetlana25@mail.ru 


\title{
Эффективность профессионального развития педагога в процессе повышения квалификации: анализ образовательных потребностей учителей
}

\author{
С.О. Петрова \\ Северо-Восточный федеральный университет имени М. К. Аммосова \\ Российская Федерачия, Якутск
}

\begin{abstract}
Аннотация. Цель исследования заключалась в определении оптимального вида обучения в ходе повышения квалификации для профессионального развития педагогов и выявлении ожидаемых ими результатов от данного процесса. Проведено анкетирование педагогических работников общеобразовательных учреждений из 3 городов и 25 районов Республики Саха. На основе полученных результатов и выводов рекомендована разработка курсов ПК с «аналитической» структурой, ориентированной на организацию консультационного сопровождения слушателей в течение всего курса, решение кейсов в школьном контексте, обзор стратегий, подходящих для решения актуальной учебной задачи. Данная структура подходит как для онлайнобучения, так и для очной его формы. Помимо этого, требуется отдельный курс ПК по формированию и развитию профессиональной этики педагога в дистанционном и очном форматах обучения. Это можно рассматривать как актуальную задачу деятельности современного учителя, от которой зависит успешность реализации государственной политики в сфере образования.
\end{abstract}

Ключевые слова: повышение квалификации, курсы повышения квалификации, непрерывное профессиональное развитие педагога, профессиональный стандарт педагога.

Научная специальность: 13.00 .08 - теория и методика профессионального образования.

\section{Introduction}

The teacher is a key figure in the educational process. Therefore, the process of teacher's training for the purpose of professional development should be as effective as possible, allowing educators to actualize their knowledge and skills. Professional development (PD) of teachers has a positive impact both on their work and on the students' performance. Even experienced teachers need PD to keep up with new requirements in the educational system and teach students effectively. And for young teachers PD is very important, too.

\section{Theoretical framework} and statement of the problem

We believe that in order to teach effectively a teacher must have developed verbal intelligence, extensive content knowledge, and pedagogical experience, which is described in his or her current portfolio. Verbal intelligence is a teacher's ability to convey instructional content to students through words and actions, which has a positive impact on their performance and development. The portfolio is a generalized documented indicator of the level of preparedness, activity and selfimprovement of the teacher, which shows the effectiveness of his/her pedagogical activity. It is established that after the first five years of work the effectiveness of pedagogical activity reaches its maximum, and then on the tenth year of work it decreases significantly if the teacher does not update his/her knowledge (Baiborodova, 2008). Therefore, teachers need to periodically / constantly improve their qualifications for professional development. The Russian professional standard of a teach- 
er includes several differentiated levels of professional development: beginner (the level is assigned by the results of successful passing the qualification exam), advanced teacher (activity with mastering various competencies), teacher-methodologist (practices the methods and technologies of training and education at a high level), teacher-researcher (a mentor who carries out approbation and implementation of innovative technologies) (Godunov, 2019).

According to the Federal Law «On Education in Russian Federation» (No. 273 dated December 29, 2012), the quality of education depends on the professional development of the teacher. Paragraph 1.5 of Article 48 states that educators should use forms and methods of teaching and education that ensure a high quality of education. Paragraph 5.2 of Article 47 prescribes that at least once every three years teachers have the right to additional professional education in the profile of their teaching activities. Article 48, paragraph 1.7 declares that systematic improvement of one's professional level is a responsibility of an educator (Merkur'ieva, 2021).

\section{Methods}

As part of the analytical study, there was conducted a questionnaire survey among 244 teachers of general educational institutions from 3 cities and 25 districts of the Sakha Republic, the results were processed using descriptive statistics methods. The questionnaire was distributed among the teachers in Google forms. $100 \%$ of teachers who participated in the survey are specialists with at least two years of teaching experience. Most of them $(98 \%)$ have a basic pedagogical education, and the remaining $2 \%$ have completed professional retraining courses granting them with the «Teacher» qualification. The questionnaire consisted of an open introductory question (asking respondents to indicate their place of work: name of the educational institution, city/ village, and basic education), 21 multi choice questions, each of which included several options from which the respondent could choose one, and 8 open questions. The questionnaire touched on topics such as the form and duration of the PD course, the level of qualification of course instructors, the quality of training, teaching materials, the advantages and disadvantages of the course, whether the course met the expectations of students, use of information technology in the PD process, distribution of the studied material among colleagues, the practical importance of the studied material, the availability of articles published in scientific journals. Having processed the data, I calculated the percentages for each answer, the valid percentage, and the cumulative percentage.

\section{Results}

The respondents have different teaching experience (Table 1). Most (60\%) have teaching experience ranging from 2 to 10 years, $12 \%$ have pedagogical experience of more than 20 years. Teachers with the first qualification category prevail, but almost one third of teachers have no category.

Table 1 shows that $100 \%$ of the teachers took the PD courses in a face-to-face or distance learning format. Most of them (66\%) took 1 to 7 days of training, $23 \%$ took 8 to 10 days, and the remaining $10 \%$ took more than 11 days but less than a month. According to the results of the survey, all teachers of the courses were highly qualified specialists with different levels of education: from a bachelor's degree in pedagogical direction to a $\mathrm{PhD}$ in pedagogical sphere. The majority of the courses $(61 \%)$ are taught by lecturers with a diploma of specialist, $15 \%$ - with a bachelor's degree, $22 \%$ - with a master's degree, and $6 \%$ - with $\mathrm{Ph} \mathrm{D}$.

The respondents also indicated in their response to open-ended question \#1 that course instructors used different teaching methods: a combination of lectures and Power Point presentations, lectures and mini-group discussions, questions and answers, introductory discussions at the beginning of classes, a combination of lectures and watching videos, mini conferences at the end of the course to share experiences involving all trainees. However, $25 \%$ of the teachers surveyed claim that the lectures were not accompanied by visual supports, they were only supported by a questionand-answer format.

The results of the survey also show that the training materials covered current issues of 
Table 1. Pedagogical experience and qualification category of respondents, the duration of PD courses and the level of education of the course instructor

\begin{tabular}{|c|c|c|c|c|}
\hline Answer options & $\begin{array}{c}\text { Frequency } \\
\text { (number of answers) }\end{array}$ & Percent & Valid percentage & $\begin{array}{l}\text { Cumulative } \\
\text { percentage }\end{array}$ \\
\hline \multicolumn{5}{|c|}{ Pedagogical experience } \\
\hline Less than 5 years & 80 & 33 & 33 & 33 \\
\hline $5-10$ years & 69 & 27 & 27 & 60 \\
\hline $11-15$ years & 41 & 17 & 17 & 77 \\
\hline $16-20$ years & 26 & 11 & 11 & 88 \\
\hline $21-25$ years & 21 & 9 & 9 & 97 \\
\hline 26 years and more & 7 & 3 & 3 & 100 \\
\hline \multicolumn{5}{|c|}{ Qualification category } \\
\hline First & 112 & 46 & 46 & 46 \\
\hline Higher & 52 & 21 & 21 & 67 \\
\hline No category & 80 & 33 & 33 & 100 \\
\hline \multicolumn{5}{|c|}{ Completion of PD courses } \\
\hline Yes & 244 & 100 & 100 & 100 \\
\hline No & 0 & 0 & 0 & 100 \\
\hline \multicolumn{5}{|c|}{ PD course duration } \\
\hline $0-4$ days & 81 & 33 & 33 & 33 \\
\hline 5-7 days & 80 & 33 & 33 & 66 \\
\hline $8-10$ days & 55 & 23 & 23 & 89 \\
\hline 11-14 days & 13 & 5 & 5 & 94 \\
\hline 15-30 days & 13 & 5 & 5 & 99 \\
\hline More than 30 days & 2 & 1 & 1 & 100 \\
\hline \multicolumn{5}{|c|}{ Education level of a course instructor } \\
\hline Bachelor's degree & 36 & 15 & 15 & 15 \\
\hline Master's degree & 53 & 22 & 22 & 37 \\
\hline Specialty & 149 & 61 & 61 & 97 \\
\hline $\mathrm{PhD}$ & 6 & 3 & 3 & 100 \\
\hline
\end{tabular}

changes in the federal standards, the features of the professional standard of a teacher, the structure of the modern lesson, competencies of the teacher, the latest learning technologies, analysis of their own lessons (open question \#2). Topics related to the organization of extracurricular activities, self-education of a young teacher were also studied, but there was no information about publications in scientific journals.

Most respondents believe that they participated quite actively in all PD activities, such as questions to lecturers, filling out worksheets in pairs or in groups, participating in intragroup and intergroup discussions, modelling the practical part of classes (open question \#3). However, few of them (23\%) managed to successfully implement the knowledge obtained during the PD into their daily practice.

In any case, according to the respondents, it is necessary to attend PD courses. According to Table 2, $99 \%$ agreed with the productivity of the courses and only $1 \%$ disagreed. In terms of achieving an individual goal, $62 \%$ of respondents consider that the training in the courses met their needs. However, $38 \%$ of 
them assert that the training did not meet their expectations.

Based on the information in Table 2, we can conclude that almost all respondents (98\%) agreed that the content of the learning activities was of good quality. Only $2 \%$ disagreed with this statement. $97 \%$ of respondents admitted that the training was innovative, and only $3 \%$ did not share this opinion. The majority (75\%) of respondents attended open classes in schools during the PD.

According to the teachers' opinions, all courses' activities had advantages and disadvantages. On the one hand, the training helped to improve their competence. Experienced and creative instructors provided them with useful materials, taught them how to develop innovative teaching models. Teachers were given ample opportunities to develop practical activities and to actively participate in course seminars $(10 \%)$. On the other hand, there were some shortcomings: imbalance between theory and practice $(60 \%)$, insufficient time for assignments, use of predominantly monologic speech in explaining material, limited teaching time and lack of time for talking and answering questions (open-ended question \#4).
According to the respondents, when entering the PD courses they had the following expectations: they wanted to increase the level of professional knowledge, to learn about topical issues of education, to develop plans for the generalization of teaching experience, to improve competence in working with parents and conflict resolution, to develop critical thinking skills, to advance teaching with modern technology, to get educational materials on electronic media, to get help with developing working programmes, to disseminate the obtained knowledge (open-ended question \#5).

Teachers prefer training that consists of a small portion of theory with a presentation and practical part in schools under expert guidance. They justify their preference for the following reasons: practice allows for better assimilation of material, it is more useful for organizing high-quality and modern lessons, it contributes significantly to professionalism and has a longterm positive impact on teaching skills (openended question \#6).

Some teachers $(4 \%)$ characterized their expectations from the courses further: the ideal ratio between theory, practice, and a closing

Table 2. Productivity of courses, quality and innovation of their content, visiting open lessons

\begin{tabular}{|c|c|c|c|c|}
\hline Answer options & $\begin{array}{c}\text { Frequency } \\
\text { (number of answers) }\end{array}$ & Percent & Valid percentage & $\begin{array}{l}\text { Cumulative } \\
\text { percentage }\end{array}$ \\
\hline \multicolumn{5}{|c|}{ Course productivity } \\
\hline No & 2 & 1 & 1 & 1 \\
\hline Yes & 242 & 99 & 99 & 100 \\
\hline \multicolumn{5}{|c|}{ Achieving an individual goal } \\
\hline No & 92 & 38 & 38 & 38 \\
\hline Yes & 152 & 62 & 62 & 100 \\
\hline \multicolumn{5}{|c|}{ Quality content } \\
\hline No & 4 & 2 & 2 & 2 \\
\hline Yes & 240 & 98 & 98 & 100 \\
\hline \multicolumn{5}{|c|}{ Innovative content } \\
\hline No & 8 & 3 & 3 & 3 \\
\hline Yes & 236 & 97 & 97 & 100 \\
\hline \multicolumn{5}{|c|}{ Attendance of open classes } \\
\hline No & 60 & 25 & 25 & 25 \\
\hline Yes & 184 & 75 & 75 & 100 \\
\hline
\end{tabular}


seminar should be $25 \%, 50 \%$, and $25 \%$, respectively; also, they would like to visit open lessons concerning children with disabilities, learn innovative teaching methods in practice, receive methodological assistance and training by lecturers from foreign schools (open-ended question \#7).

According to Table 3, $98 \%$ of those surveyed believe that the use of high-speed Internet is necessary in the learning process. Only $2 \%$ acknowledge it does not matter. $77 \%$ of the respondents said that their ICT competence had improved, while $23 \%$ said it had not. According to $99 \%$ of teachers, the use of ICT in the teaching process in PD courses is important.

The benefits of the teacher's ability to use ICT in the classroom include visual aids to ask students to review assignment recommendations, strengthen students' interest in learning, find a variety of learning materials, facilitate the organization of students' research activities, increase the effectiveness of the learning process as a whole, enrich learning tools with interactive forms, automatically grade students' work (using online workbooks) and visualize theory.
In terms of skills, $83 \%$ of respondents state that they successfully used the knowledge they had acquired in previous courses in the last course they took, while $17 \%$ did not use the skills acquired in previous classes. Most respondents $(75 \%)$ are ready to disseminate the knowledge gained during the PD courses among their fellow teachers through in-school seminars, exchange of training materials and experience with them in online communication (Table 3).

Table 4 shows that $81 \%$ of respondents never conducted pedagogical research and only $19 \%$ use the «action research» method. Its application is important for teachers due to a number of reasons: it allows them to better assess student achievement, develop their own research skills, solve problems in the classroom more effectively through empirical procedures, move up the career ladder, develop their professionalism, assess the success of their own teaching, improve the learning process, select optimal teaching tools, and organise selfreflection to identify weaknesses in the methodology used.

According to Table 4, $69 \%$ of teachers need training in the «action research» meth-

Table 3. ICT competence, application and dissemination of previously acquired skills

\begin{tabular}{|c|c|c|c|c|}
\hline Answer options & $\begin{array}{c}\text { Frequency } \\
\text { (number of answers) }\end{array}$ & Percent & Valid percentage & $\begin{array}{l}\text { Cumulative } \\
\text { percentage }\end{array}$ \\
\hline \multicolumn{5}{|c|}{ Need to use a high-speed Internet connection } \\
\hline No & 3 & 2 & 2 & 2 \\
\hline Yes & 241 & 98 & 98 & 100 \\
\hline \multicolumn{5}{|c|}{ Development of ICT competency } \\
\hline No & 55 & 23 & 23 & 23 \\
\hline Yes & 189 & 77 & 77 & 100 \\
\hline \multicolumn{5}{|c|}{ The importance of using ICT in the learning process in the courses } \\
\hline No & 2 & 1 & 1 & 1 \\
\hline Yes & 244 & 99 & 99 & 100 \\
\hline \multicolumn{5}{|c|}{ Applying previously acquired skills } \\
\hline No & 41 & 17 & 17 & 17 \\
\hline Yes & 203 & 83 & 83 & 100 \\
\hline \multicolumn{5}{|c|}{ Dissemination of previously acquired skills } \\
\hline No & 60 & 25 & 25 & 25 \\
\hline Yes & 184 & 75 & 75 & 100 \\
\hline
\end{tabular}


Table 4. Application of the «action research» method, opinions on this method, scientific publications of teachers

\begin{tabular}{|c|c|c|c|c|}
\hline Answer options & $\begin{array}{c}\text { Frequency } \\
\text { (number of answers) }\end{array}$ & Percent & Valid percentage & $\begin{array}{l}\text { Cumulative } \\
\text { percentage }\end{array}$ \\
\hline \multicolumn{5}{|c|}{ Application of the action research method in pedagogical activities } \\
\hline No & 198 & 81 & 81 & 81 \\
\hline Yes & 46 & 19 & 19 & 100 \\
\hline \multicolumn{5}{|c|}{ The need for «action research» training } \\
\hline No & 8 & 3 & 3 & 3 \\
\hline Yes & 169 & 69 & 69 & 72 \\
\hline $\begin{array}{l}\text { No answer } \\
\text { was given }\end{array}$ & 67 & 28 & 28 & 100 \\
\hline \multicolumn{5}{|c|}{ Experience in writing scientific articles } \\
\hline No & 198 & 81 & 81 & 81 \\
\hline Yes & 46 & 19 & 19 & 100 \\
\hline \multicolumn{5}{|c|}{ Importance of scientific publications } \\
\hline No & 67 & 26 & 26 & 26 \\
\hline Yes & 137 & 56 & 56 & 82 \\
\hline $\begin{array}{l}\text { No answer } \\
\text { was given }\end{array}$ & 40 & 18 & 18 & 100 \\
\hline \multicolumn{5}{|c|}{ Availability of scientific publications } \\
\hline No & 188 & 77 & 77 & 77 \\
\hline Yes & 56 & 23 & 23 & 100 \\
\hline \multicolumn{5}{|c|}{ Difficulties in research activity } \\
\hline No & 72 & 30 & 30 & 30 \\
\hline Yes & 9 & 4 & 4 & 34 \\
\hline $\begin{array}{l}\text { No answer } \\
\text { was given }\end{array}$ & 163 & 66 & 66 & 100 \\
\hline
\end{tabular}

od, namely in terms of the formulation of a research problem (self-education plan for young teachers), research methodology, including instrumentation, data analysis, and report writing. Regarding the research aspect of professional development, the majority of respondents $(81 \%)$ had no experience writing research papers. Only $19 \%$ of them had tried scientific writing. As Table 4 shows, $56 \%$ of teachers said that writing scientific articles is necessary to enhance their professional development. However, $26 \%$ considered it unnecessary and other teachers chose to leave this question unanswered altogether. The data in Table 4 indicate that there is an urgent need for teachers to increase their level of research activity. It should be noted that $77 \%$ of them have never written scientific articles and only $23 \%$ have tried their hand at this type of work. $72 \%$ have experienced difficulty writing research papers, and only $4 \%$ have managed to do so without difficulty.

The last question of the questionnaire (\#8) was of the open-ended type and required naming of the course containing the most important content, taking into account the conditions of the modern school. $84 \%$ of respondents indicated ethics in the professional activities of a teacher in both face-to-face (29 \%) and distance learning (55\%).

\section{Discussion}

Based on the survey results, it is obvious that teachers express two types of opinions 
with regard to PD courses: satisfactory and unsatisfactory. Taking into account that the majority of teachers have less than 10 years of experience in schools, we may assume that this fact may influence their teaching style, choice of teaching tools, didactic materials, etc. Teaching experience of 2-10 years can be called the «golden period» for pedagogical effectiveness. We believe that effective teachers are those who have brilliant oratory skills, excellent knowledge of the subject, research talents, and experience.

Respondents also noted that the materials presented to them in the PD courses were of high quality and innovative, and that the training methods differed from one another. But good training can be ineffective if the courses are conducted for a limited time (this was the reason for the dissatisfaction of a number of trainees). Dissatisfaction was also caused by the fact that, in the opinion of teachers, not all PD courses were effective in the sense that the material was not studied to the full, training was conducted during too short period of time.

However, instructors in courses work hard to have time to present all materials within a limited period of time. Consequently, they focus on one-way interaction (emphasis on the instructor) rather than two-way interaction (emphasis on the instructor and the students) to save time. The ratio of theory to practice can also be unbalanced. In addition, despite their experience, some course instructors are unable to get students to learn $100 \%$ of the course material. Andragogy teachers have been known to find it very difficult to make significant progress in training if it takes only a few days (Mandel, 2019). As a rule, they have to do a lot of work on drawing up a high-quality syllabus, rehearsing classes beforehand.

Other important issues are related to the use of information technology in PD courses, the continuity of learning and scientific writing. Research by B.R. Mandel shows that trainees who used information technologies in their studies showed significant progress not only in the sphere of knowledge and creativity, but also in the development of critical thinking (Mangal, 2019). That is why continuity of professional development and continuous professional development for teachers are critical. As it follows from the results of the questionnaire, the knowledge and skills they acquire during the PD are effective only in action. It is easy to lose them after returning to routine training cases. One important measure to ensure continuity is the exchange of experience with colleagues and the publication of scholarly articles.

\section{Conclusion}

The following conclusions can be drawn from the analysis of the data presented. First, teachers learn the material better in practice. Second, the practical part of most PD courses is not large enough (they are realized at only national/regional level), so it is necessary to involve foreign teachers in order to exchange international experience. Third, many trainees believe that the limited duration of the PD is the reason for incomplete training in some courses which reduces its effectiveness.

We recommend developing PD courses with an analytical structure focused on organizing consultative support for students throughout the course, solving cases in the school context and reviewing strategies appropriate for problem solving at the school (classroom) level. This course structure will enable teachers to develop skills in planning, observing, evaluating and reflecting upon their work. The process of reflection training builds confidence in the trainees' ability to design a course of study and deal effectively with professional difficulties. This structure is suitable for both online and face-to-face training. In addition, a separate PD course on the creation and development of professional ethics of a teacher in distance and face-to-face learning formats is required. This can be seen as an urgent task of the modern teachers' society, which the success of the state policy in the educational sphere depends on. 


\section{References}

Baiborodova, L.O. (2008). Osnovy uchebno-issledovatel'skoi deiatel'nosti [The basis of study and research activity]. Moscow, Urait, $221 \mathrm{p}$.

Godunov, I.V. (2019). Innovatsionnye modeli upravleniia i naukometricheskie issledovaniia $v$ sfere obrazovaniia [Innovational models of management and scientometric researches in education]. Moscow, IAI RAS, 388 p.

Mandel, B.R. (2019). Andragogika: istoriia i sovremennost', teoriia i praktika [Andragogy: history and modernity, theory and practice]. Moscow, Direct-Media, $412 \mathrm{p}$.

Mangal, S. K. (2019). Learning and teaching. Delhi, PHI Learning Pvt. Ltd., 584 p.

Merkur'ieva A. A. (2021). Federal'nyi zakon «Ob obrazovanii v Rossiiskoi Federatsii» [Federal Law «On Education in Russian Federation»]. Moscow, LitRes, 160 p. 